\title{
Mesozooplankton Distribution in Kavaratti Atoll, Lakshadweep Archipelago, South West Coast of India with Special Reference to Calanoid Copepods
}

\author{
V.F. Sanu, S. Bijoy Nandan*, M. Rithin Raj and R. Radhika \\ Dept. of Marine Biology, Microbiology and Biochemistry, School of Marine Sciences, \\ Cochin University of Science and Technology, Cochin- 682016, India
}

\begin{abstract}
Lakshadweep archipelago is a group of coral Islands on the West coast of the Arabian Sea. It is one among the unique coral atolls in India that are well known for several species of fishes and other biotic resources. Seasonal variation in mesozooplankton, particularly of copepod abundance and distribution in the inner and outer lagoon of Kavaratti atoll were studied during April 2013 (premonsoon), September 2013 (monsoon) and January 2014 (postmonsoon). Copepods were the most dominant taxa in all the stations and seasons, that accounted 44.15 to $85.97 \%$ of the total mesozooplankton abundance. Ostracoda (premonsoon), crustacean larvae (monsoon) and chaetognaths (postmonsoon) formed the abundant groups in the respective seasons. Mesozooplankton community in the study area exhibits temporal variation corresponding to the variation in abiotic parameters therefore can be used as potential indicators of water quality. Calanoid copepods formed the dominant taxa during monsoon and postmonsoon, while cyclopoid copepods dominated during premonsoon. Among the copepods, species of the family Candacidae, Calanidae, Pontellidae, Temoridae, Psuedodiaptomidae, Centropagidae and Oithonidae were predominant. The ten species of calanoids were previously not reported from Kavaratti atoll, in Lakshadweep.
\end{abstract}

Keywords: Calanoids, Copepods, Coral Atoll, Kavaratti, Mesozooplankton

\section{Introduction}

Zooplankton plays an important role in structuring and regulating the coastal marine food web and also in the functioning of biological pump (Chiba et. al. 2006). As their community structure and function are highly susceptible to changes in the environmental conditions regular monitoring of their distribution as well as their interactions with various physico chemical parameters is inevitable for the sustainable management of the ecosystem (Kusum et. al. 2014). Of all the marine zooplankton groups, copepods particularly calanoid copepods are the dominant groups in marine subtropical and tropical waters and exhibit great diversity in morphology and habitats they occupy (Madhupratap, 1991; Cornils et. al. 2005). Further, copepods are significant in fisheries as it forms an important food item to the fishes, maintaining regenerated primary production and carbon flux (Madhupratap, 1997). Coral islands in Lakshadweep, endowed with unique diversity and productivity are of great ecological and socio-economic importance (Bakus, 1993). Kavaratti is a perfect atoll of the Lakshadweep archipelago and the Island is oriented along North-South axis with shallow lagoon enclosed by coral reef on the West. A constant flow of water from sea to lagoon is maintained by the action of surf which breaks across the reef and the coral reef beaches are exposed only during the low tide (Qasim and Sankaranarayanan, 1970).

Though there are a few studies reported on quantitative and qualitative distribution of mesozooplankton in Kavaratti (Qasim et. al.1972; Tranter and George, 1972; Goswami, 1973; 1979, Madhupratap et. al. 1977), they are based on short time observations. The present study is aimed to develop a baseline data on mesozooplankton abundance, distribution and seasonal variation in Kavaratti atoll in relation to various hydrographical parameters. The focus is on species diversity and distribution of calanoid copepods.

Study area

\section{Materials and methods}

The Union territory of Lakshadweep located in the Arabian sea comprises of a group of 11 inhabited islands, 25 uninhabited tiny islands and 3 coral reef environments situated between $8^{\circ}-12^{\prime} \mathrm{N}$ latitude and $71^{\circ} 45^{\prime}$ $-73^{\circ} 45^{\prime} \mathrm{E}$ longitude. The Kavaratti lagoon has a length of about 6 kilometer and an area of 4.96 square kilometers with an average depth of 2 meters. Field sampling for the collection of mesozooplankton and various physico chemical parameters were conducted during April 2013 (premonsoon), September 2013 (monsoon) and January 2014 (postmonsoon). The exact sampling locations were fixed by global positioning system (GPS) (Magellan ®Ttriton 200/300). Samples were collected from three stations, one in the inner lagoon (T2) and the 
other two stations in the outer lagoon, in which one was in the coral area (T1) and the other in boat channel (T3) (Fig.1).

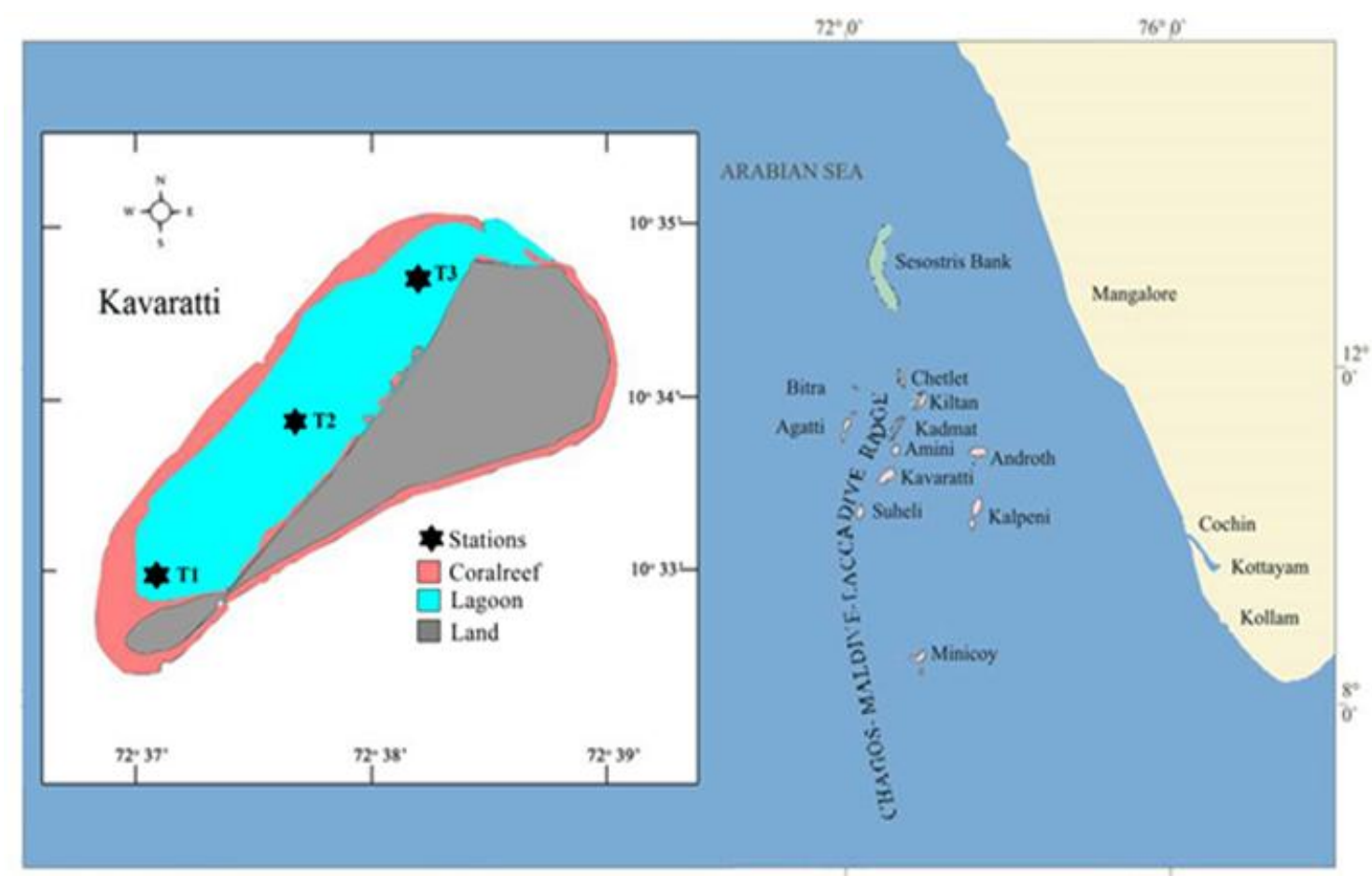

Fig. 1. Map showing the sampling stations at Kavaratti atoll, Union Territory of Lakshadweep.

\section{Sampling and analysis}

The subsurface water samples were collected using Niskin water sampler (General Oceanics-5L). Temperature, salinity and $\mathrm{pH}$ were measured using probes (Eutech model number PCD 650). Dissolved oxygen concentration was measured by Winkler's method (Strickland and Parsons, 1972). For chlorophyll a (Chl-a) analysis, water samples were filtered immediately after collection and estimated based on standard procedure (APHA, 2005). For inorganic nutrients, nitrate-nitrogen, nitrite-nitrogen, phosphate-phosphorous, silicatesilicon and ammonia-nitrogen, samples were acidified with conc. $\mathrm{HNO}_{3}$ and analysed based on standard methods (Grasshoff et. al. 1999). Mesozooplankton was collected using a plankton net (mesh size 200 $\mu \mathrm{m})$ with a mouth area of $0.28 \mathrm{~m}^{2}$. The net was attached with a calibrated flow meter (General Oceanics model number2030 R 2012) and was towed horizontally just below the surface with a fixed speed of $\sim 1$ knot for the duration of 10 minutes. The samples were then preserved in $4 \%$ buffered formalin prepared in seawater. Zooplankton biomass was estimated by displacement volume method and expressed as $\mathrm{ml} / \mathrm{m}^{3}$ (Harris, 2000; Goswami, 2004; Johnson and Allen, 2005). Samples were sorted at group level for the major zooplankton taxa (Tait, 1981; Omori et. al. 1984; Todd and Laverack, 1991) and enumerated and density was expressed in individuals $/ \mathrm{m}^{3}$ (Goswami, 2004; Johnson \& Allen, 2005). All the rarely occurring groups are included in "other groups". The calanoid, cyclopoid and harpacticoid copepods were further identified upto species level using standard keys (Mori, 1964; Sewell, 1947a; 1948b; Kasturirangan, 1963; Wellershaus, 1969; Bradford and Jillet, 1980; Bradford and Grieve, 1994; Conway et. al. 2003).

Multi-dimensional scaling (MDS) ordination, following hierarchical cluster using SIMPROF were constructed based on fourth root transformation on mesozooplankton taxa abundance (Clarke and Gorley, 2006). Calanoid species abundance was subjected to univariate measures such as Shannon-wiener diversity index $\left(\mathrm{H}^{\prime}\right)$, Margalef's richness (d), Pielou's evenness (j') and Simpson's dominance (lambda). All these were performed in statistical software PRIMER version 6.1(Clarke and Gorley, 2006). The significance of variation of abiotic and biotic factors were analyzed using a two-factor analysis of variance (ANOVA) without replication and Pearson correlation analysis was employed to determine the correlations between various abiotic factors and biotic parameters using SPSS version 16.

\section{Results}

During the study period, temperature and $\mathrm{pH}$ in the region exhibited significant seasonal variation $(\mathrm{p}<0.05)$. Temperature ranged from $27^{\circ} \mathrm{C}$ to $30^{\circ} \mathrm{C}$ with the lowest value during monsoon and highest value 
during postmonsoon. $\mathrm{pH}$ fluctuated between 7.72 and 8.76 with the lowest and highest value observed during monsoon and postmonsoon respectively. The salinity values ranged between 33psu during monsoon and 37psu during postmonsoon without any marked spatial variation. Dissolved oxygen concentration exhibited a saturated condition in all the seasons and showed statistically significant variation $(p<0.05)$ between the stations. However, in all the seasons comparatively the highest dissolved oxygen value was recorded near the boat channel $(6.11$ to $6.95 \mathrm{mg} / \mathrm{l})$ and the minimum value in the coral area $(5.94 \mathrm{mg} / \mathrm{l})$. Turbidity tends to show the highest value during monsoon (3.21) near the boat channel and the least (2.15) during premonsoon in the inner lagoon. Seasonal variation in physico-chemical parameters are shown in Table 1.

Table 1. Premonsoon, monsoon and postmonsoon seasonal average of hydrographical parameters in Kavaratti

\begin{tabular}{|c|c|c|c|}
\hline Parameter & Premonsoon & Monsoon & Postmonsoon \\
\hline $\begin{array}{l}\text { Water temperature }\left({ }^{\circ} \mathrm{c}\right) \\
\text { pH } \\
\text { Turbidity }(\mathrm{NTU}) \\
\text { Salinity }(\% \mathrm{o}) \\
\text { Dissolved Oxygen }(\mathrm{ml} / \mathrm{l}) \\
\text { Nitrate }(\mu \mathrm{m} / \mathrm{l}) \\
\text { Nitrite }(\mu \mathrm{m} / \mathrm{l}) \\
\text { Phosphate }(\mu \mathrm{m} / \mathrm{l}) \\
\text { Silicate }(\mu \mathrm{m} / \mathrm{l}) \\
\text { Ammonia }(\mu \mathrm{m} / \mathrm{l}) \\
\text { Chlorophyll A }\left(\mathbf{m g} / \mathrm{m}^{3}\right)\end{array}$ & $\begin{array}{c}28.67 \pm 0.58 \\
8.64 \pm 0.41 \\
1.45 \pm 0.04 \\
34 \pm 0.00 \\
6.02 \pm 0.09 \\
2.35 \pm 0.30 \\
0.43 \pm 0.01 \\
0.34 \pm 0.03 \\
0.45 \pm 0.02 \\
0.37 \pm 0.02 \\
0.51 \pm 0.05\end{array}$ & $\begin{array}{c}27.33 \pm 0.58 \\
7.75 \pm 0.03 \\
3.19 \pm 0.02 \\
33 \pm 0.00 \\
6.24 \pm 0.09 \\
3.1 \pm 0.3 \\
0.51 \pm 0.02 \\
0.40 \pm 0.02 \\
0.30 \pm 0.02 \\
0.35 \pm 0.02 \\
0.46 \pm 0.05\end{array}$ & $\begin{array}{c}29.67 \pm 0.58 \\
8.75 \pm 0.01 \\
2.28 \pm 0.01 \\
37 \pm 0.00 \\
6.89 \pm 0.07 \\
3.03 \pm 0.40 \\
0.49 \pm 0.03 \\
0.39 \pm 0.01 \\
0.31 \pm 0.01 \\
0.40 \pm 0.02 \\
0.53 \pm 0.04\end{array}$ \\
\hline
\end{tabular}

The spatial and temporal variation in nitrate-nitrogen, nitrite-nitrogen, phosphate-phosphorous, and silicate-silicon were not significant. However, the highest values of nitrate $(3.2 \mu \mathrm{m} / \mathrm{l})$, nitrite $(0.53 \mu \mathrm{m} / \mathrm{l})$ and phosphate $(0.39 \mu \mathrm{m} / \mathrm{l})$ were recorded during monsoon in the coral area $(\mathrm{T} 1)$, while the lowest values were recorded in the inner lagoon during premonsoon except for phosphate, which showed lowest value in the coral area during postmonsoon $(0.29 \mu \mathrm{m} / \mathrm{l})$. On the other hand, in the case of silicate, the highest value was recorded in the coral area during premonsoon $(0.47 \mu \mathrm{m} / \mathrm{l})$, whereas the lowest value $(0.29)$ was registered in the inner lagoon during monsoon. Concentration of ammonia in water showed significant spatial as well as temporal variation. Minimum and maximum values of ammonia were recorded during monsoon and postmonsoon, respectively and it ranged from 0.33 in station T3 to $0.42 \mu \mathrm{m} / 1$ in station T1. Chlorophyll a concentration showed significant seasonal variation $(\mathrm{p}<0.05)$ and the values ranged between 0.52 to $0.98 \mathrm{mg} / \mathrm{m}^{3}$ with the lowest value during postmonsoon and the highest value during premonsoon.

In contrast to a fairly small spatial variability, ANOVA analysis showed significant temporal variability $(\mathrm{p}<0.05)$ in mesozooplankton distribution. In all the three stations, it showed highest abundance during postmonsoon, reaching an average density of $1112 \mathrm{ind} . / \mathrm{m}^{3}$, while a marginal decrease in density was observed during monsoon with an average of 578 ind. $/ \mathrm{m}^{3}$. Among the stations, highest density was recorded in the coral area (243-1475 ind. $\left./ \mathrm{m}^{3}\right)$, followed by near boat channel (184-1016 ind. $\left./ \mathrm{m}^{3}\right)$ and the least in the inner lagoon (145-845 ind $\left./ \mathrm{m}^{3}\right)$ (Table 2). As far as the relationship between zooplankton abundance and abiotic parameters are concerned, it showed a positive correlation with temperature, $\mathrm{pH}$, salinity and dissolved oxygen. Considering the mesozooplankton biomass, it also showed spatial as well as seasonal variation, that was not notably significant (Figure 2). Average zooplankton biomass was the highest in the boat channel during postmonsoon $\left(0.22 \mathrm{ml} / \mathrm{m}^{3}\right)$ and the lowest biomass in the inner lagoon during monsoon season. During premonsoon season fish larvae contributed largely to the total mesozooplankton biomass. Despite lower abundance, zooplankton biomass was markedly higher in the inner lagoon during premonsoon season (Fig. 2).

Zooplankton community was composed of the members belonging to Foraminifera, Gastropoda, Bivalvia, Chaetognaths, Siphonophora, Appendicularia, Polychaeta, Ostracoda, Cladocera, Euphausiida, Decapoda, Crustacean larvae, Copepoda and ichthyoplanktons. Percentage contribution of major mesozooplanktonic groups are shown in the Figure 3. Copepods were the most abundant group irrespective of the stations and seasons (44.15 to $89.57 \%)$, followed during by decapods during monson (1.45\%), during premonsoon by fish egg and larvae $(9.52 \%)$, and during postmonsoon by chaetognaths (2.4\%). Among the copepods, calanoids ( 25.94 to $65.87 \%$ ) dominated in total mesozooplankton abundance in all the seasons, except premonsoon, when cyclopoid copepods dominated $(56.51 \%)$ and formed the second most abundant group in the remaining seasons. MDS ordination and cluster analysis on mesozooplankton abundance all the stations were grouped into three clusters PMT1, MT1, POMT1; PMT2, MT2, POMT2; PMT3, MT3, POMT3 corresponding to station T1 (Coral area), T2 (Inner lagoon) and T3 (near boat channel) respectively. Results of the hierarchical cluster analysis and MDS ordination are shown in the Figure 5 and 6. From the MDS and dendrogram it is evident that all the stations in monsoon are very similar and formed separate cluster. The remaining stations 
Mesozooplankton Distribution In Kavaratti Atoll, Lakshadweep Archipelago, South West....

showed $80 \%$ similarity, which together formed another cluster. Station PMT2 was separated from others due to the dominance of fish larvae during premonsoon.

\begin{tabular}{|c|c|c|c|c|c|c|c|c|c|}
\hline \multirow{2}{*}{$\begin{array}{l}\text { Zooplankton } \\
\text { Groups }\end{array}$} & \multicolumn{3}{|c|}{ Premonsoon } & \multicolumn{3}{|c|}{ Monsoon } & \multicolumn{3}{|c|}{ Postmonsoon } \\
\hline & T1 & T2 & T3 & T1 & $\mathrm{T} 2$ & T3 & T1 & $\mathrm{T} 2$ & T3 \\
\hline Foraminifera & $10(1.7)$ & 17(3.6) & $3(0.4)$ & 3(1.0) & $2(1.3)$ & $2(1.0)$ & $4(0.2)$ & $15(1.7)$ & $7(0.7)$ \\
\hline Gastropoda & $7(1.0)$ & $22(4.7)$ & $7(1.1)$ & $8(3.3)$ & $11(7.5)$ & $6(3.2)$ & $9(0.6)$ & $5(0.6)$ & $13(1.3)$ \\
\hline Bivalvia & $1(0.2)$ & $1(0.1)$ & 1(0.1) & 0 & 0 & $\mathbf{0}$ & $\mathbf{0}$ & $1(0.1)$ & $\mathbf{0}$ \\
\hline Chaetognatha & $5(0.7)$ & $4((0.8)$ & $7(1.1)$ & $10(4.0)$ & 11(7.5) & $5(2.7)$ & $65(4.4)$ & $7(0.8)$ & $6(0.6)$ \\
\hline Siphonophora & $3(0.5)$ & $2(0.5)$ & $4(0.6)$ & $3(1.2)$ & $2(1.3)$ & $3(1.6)$ & $5(0.3)$ & 3(0.3) & $2(0.2)$ \\
\hline Appendicularia & $5(0.8)$ & $7(1.5)$ & $1(0.2)$ & $\mathbf{0}$ & 0 & 0 & 0 & 0 & 0 \\
\hline Polychaeta & $3(0.5)$ & $1(0.3)$ & $2(0.4)$ & $\mathbf{0}$ & $1(0.6)$ & $\mathbf{0}$ & $1(0.06)$ & $\mathbf{0}$ & $\mathbf{0}$ \\
\hline Ostracoda & $5(0.8)$ & $54(11.6)$ & $5(0.7)$ & $1(0.2)$ & 1(0.6) & $1(0.5)$ & $4(0.2)$ & $7(0.8)$ & $4(0.4)$ \\
\hline Cladocera & $26(4.3)$ & $5(1.0)$ & $4(0.7)$ & 1(0.6) & 1(0.6) & $1(0.5)$ & $27(1.8)$ & $2(0.2)$ & $34(0.4)$ \\
\hline Euphausiida & $2(0.4)$ & $16((3.4)$ & $6(1.0)$ & 0 & 1(0.6) & 3(1.6) & $2(0.1)$ & $3(0.3)$ & 3(0.03) \\
\hline Decapoda & $5(0.8)$ & $15(3.2)$ & $9(1.4)$ & $25(10.2)$ & 17(11.7) & $58(31.5)$ & $4(0.2)$ & $2(0.2)$ & $2(0.2)$ \\
\hline Zoea & $7(1.1)$ & $29(6.1)$ & $18(2.7)$ & $42(17.3)$ & $35(24.1)$ & 44(23.9) & $11(0.7)$ & $2(0.2)$ & 3(0.3) \\
\hline Calanoida & $114(18.4)$ & $31(6.6)$ & $165(25.6)$ & $100(41.1)$ & $34(23.4)$ & $32(17.3)$ & $762(51.6)$ & $573(67.8)$ & $626(61.61)$ \\
\hline Cyclopoida & 298(47.9) & $70(14.9)$ & $305(47.3)$ & $39(15.8)$ & $18(12.4)$ & $16(8.6)$ & 494(33.4) & $163(19.2)$ & $262(25.8)$ \\
\hline Harpacticoida & $94(15.2)$ & $36(7.7)$ & $93(14.4)$ & $1(0.6)$ & $2(1.3)$ & $1(0.5)$ & 61(4.1) & $12(1.4)$ & 31(3) \\
\hline Copepodites & $13(2.1)$ & $25(5.4)$ & 0 & $4(1.7)$ & $3(2.0)$ & 3(1.6) & $2(0.1)$ & $2(0.2)$ & $\mathbf{0}$ \\
\hline Fish Larvae & $13(2.1)$ & $94(20.2)$ & 11(1.7) & 0 & 1(0.6) & $4(2.1)$ & $4(0.2)$ & $7(0.8)$ & $4(0.4)$ \\
\hline Fish Egg & $7(1.2)$ & $37(8.0)$ & $3(0.4)$ & $\mathbf{0}$ & 0 & $1(0.5)$ & $15(1.01)$ & $36(4.2)$ & $15(1.5)$ \\
\hline Other Groups & 3(0.4) & $2(0.5)$ & $2(0.2)$ & $6(2.4)$ & $5(3.4)$ & $4(2.1)$ & $5(0.3)$ & $5(0.6)$ & $4(0.4)$ \\
\hline Total & 621 & 468 & 646 & 243 & 145 & 184 & 1475 & 845 & 1016 \\
\hline
\end{tabular}

Table 2. Variation in abundance (ind./ $/ \mathrm{m}^{3}$ ) and percentage composition (in parenthesis) of major groups of mesozooplankton in Kavaratti atoll during 2013-14

Fig. 2. Mesozooplankton biomass $\left(\mathrm{ml} / \mathrm{m}^{3}\right)$ and density (ind. $\left./ \mathrm{m}^{3}\right)$ of Kavaratti atoll during study period.
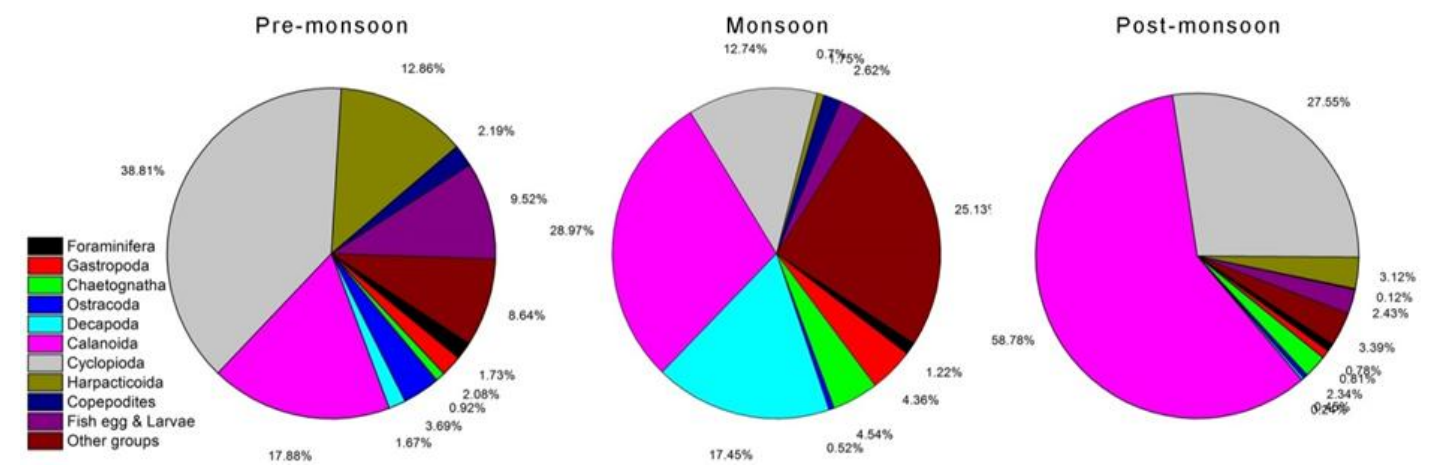

Fig. 3. Relative importance of the abundance of the different zooplankton groups observed during the study in

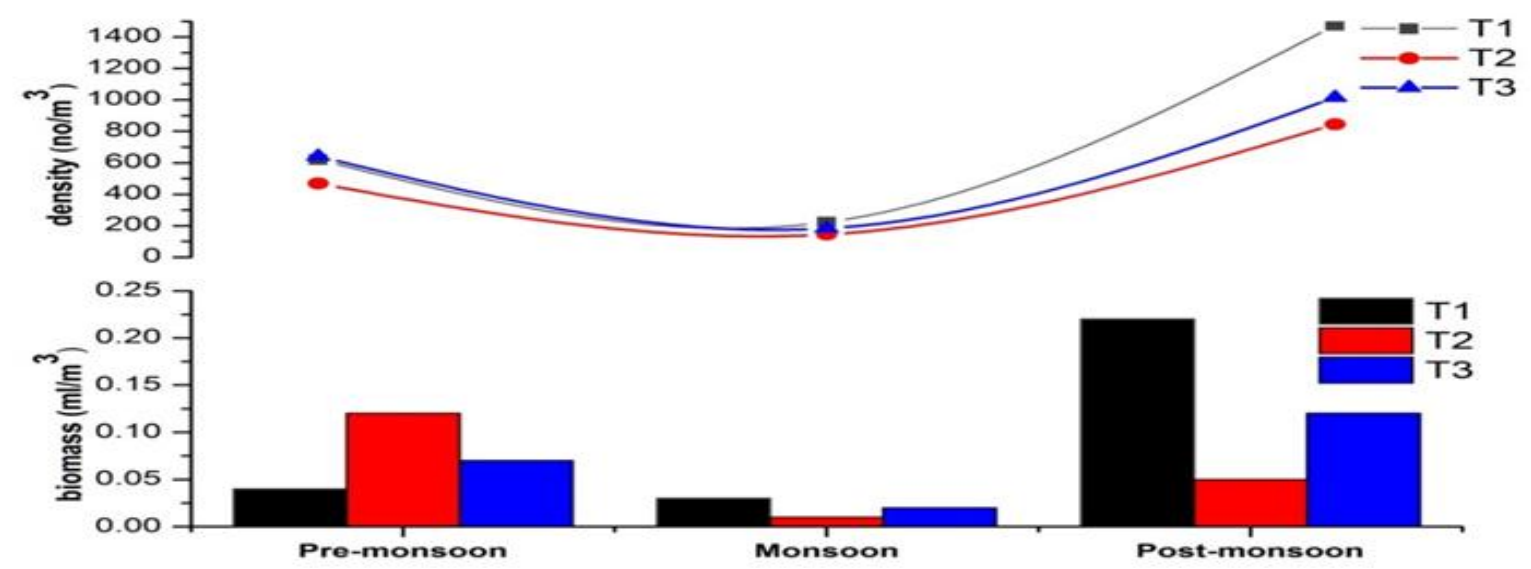

the Kavaratti atoll. 


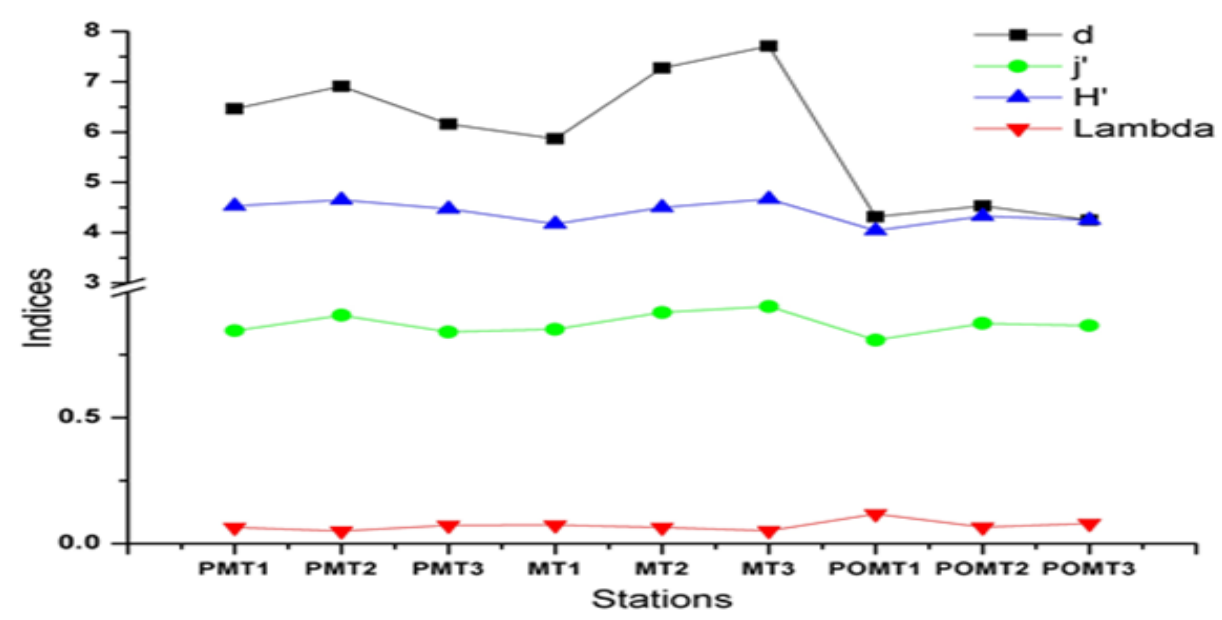

Fig. 4. Diversity indices of calanoid copepods during the study period in Kavaratti atoll.

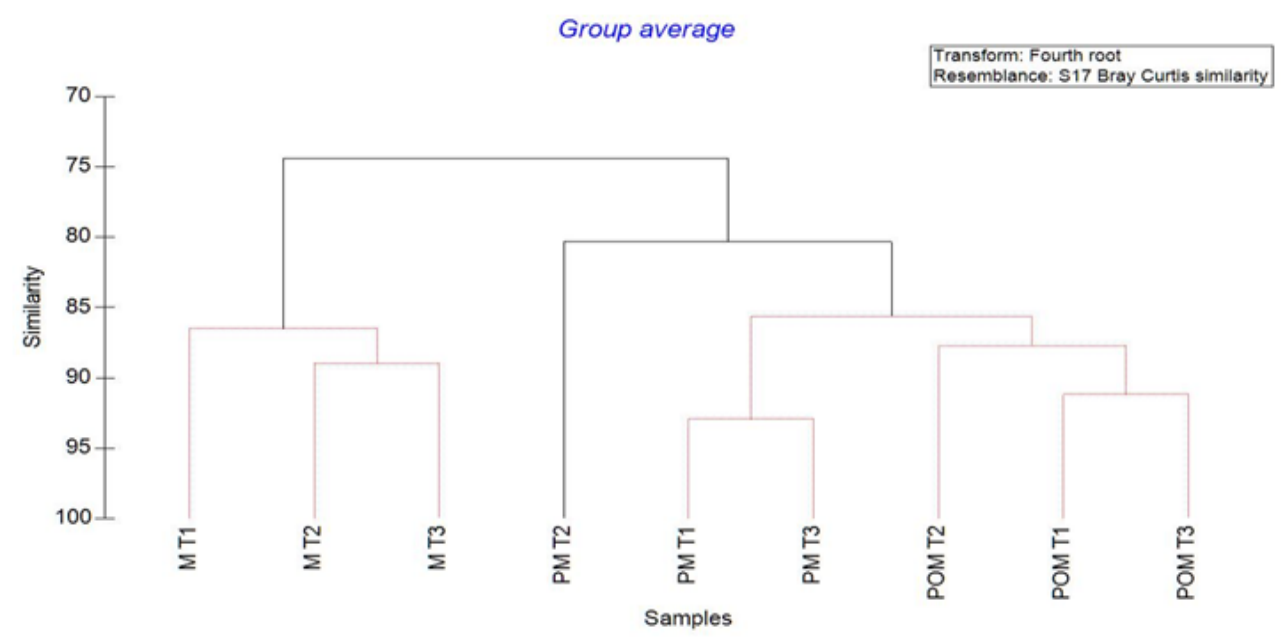

Fig.5. Hierarchical cluster analysis of the mesozooplankton during the study period of Kavaratti atoll. Transform: Fourth root
Resemblance: S17 Bray Curtis similarity

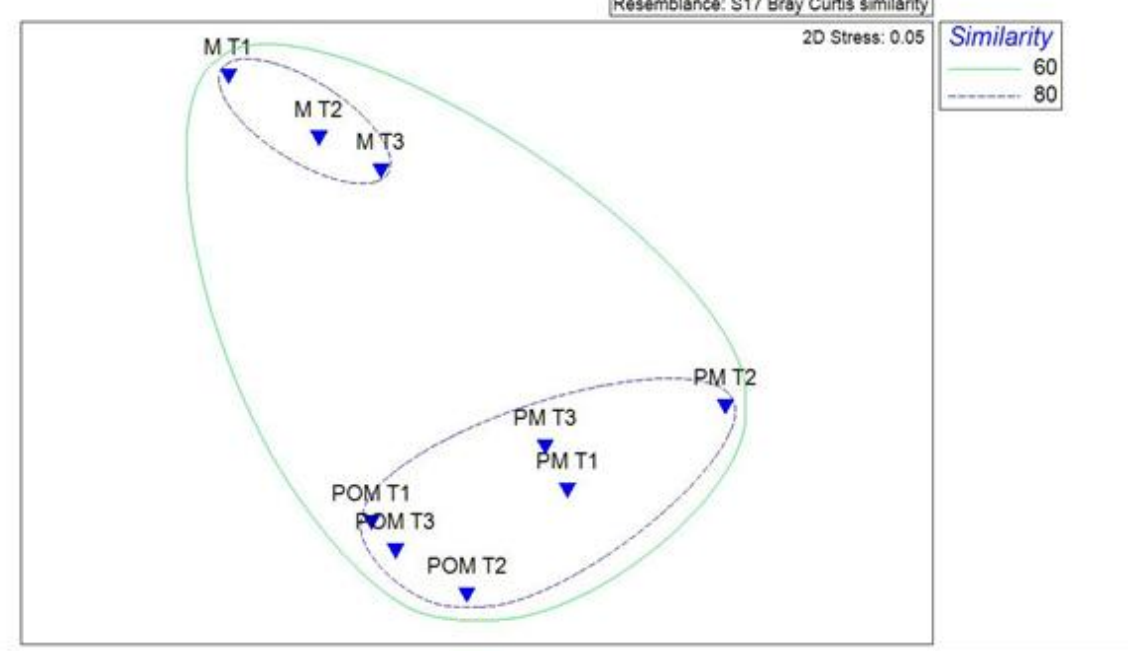

Fig. 6. Non-metric Multi-Dimensional Scaling of mesozooplankton during the study period of Kavaratti atoll. 
Mesozooplankton Distribution In Kavaratti Atoll, Lakshadweep Archipelago, South West....

Table 3. Copepod species recorded in Kavaratti atoll during 2013-2014.

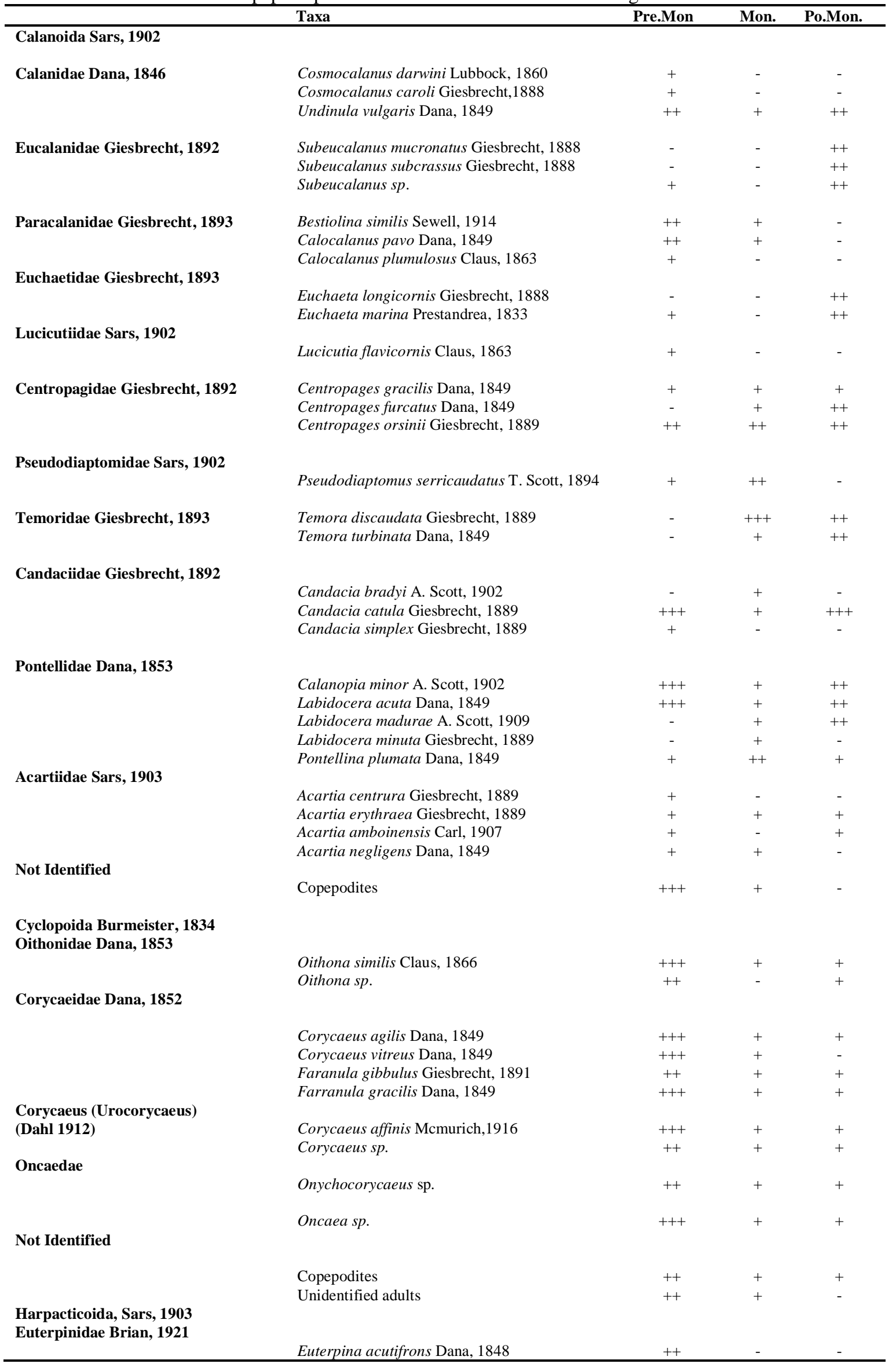


Mesozooplankton Distribution In Kavaratti Atoll, Lakshadweep Archipelago, South West....

\begin{tabular}{|c|c|c|c|c|}
\hline & Euterpina $s p$. & ++ & - & + \\
\hline \multicolumn{5}{|l|}{$\begin{array}{l}\text { Ectinosomatidae, Sars } 1909 \\
\text { Olofsson,1917 }\end{array}$} \\
\hline & Microsetella sp. & & & \\
\hline \multirow[t]{2}{*}{ Miracidae, Dana 1846} & & + & + & - \\
\hline & Distioculus sp. & & & \\
\hline \multirow[t]{4}{*}{ Not Identified } & Miracia sp. & + & - & - \\
\hline & Copepodites & + & - & + \\
\hline & Unidentified Adults & ++ & - & - \\
\hline & & + & - & + \\
\hline
\end{tabular}

“+” Denotes Presence, "++" Denotes Less Abundant, "+++" Denotes Abundant, " - "Denotes Absence

A total of 30 calanoid, 10 cyclopoids and 5 harpacticoids belonging to 17 families were identified during the study period (Table 3). Comparatively the most abundant calanoid copepod family during the study was Pontellidae having 5 species followed by Acartiidae that was represented by 4 species. Representatives of more than half (>15 species) of the total calanoid species were observed in all the seasons. The family Candacidae, Calanidae, and Pontellidae dominated in premonsoon and postmonsoon, while representatives of the family Temoridae, Pseudodiaptomidae and Centropagidae dominated in monsoon. However the species dominance pattern varies with seasons. Members of calanoid copepods in the order of their abundance during premonsoon was Labidocera acuta (3.6\%), Calanopia minor (3.5\%), Candacia catula (3.1\%) and Undinula vulgaris (3.1\%), while during postmonsoon it follows as Candacia catula (9.4\%), Labidocera acuta (5.5\%), Labidocera madurae (5.3\%), and Calanopia minor (5.3\%). In monsoon, Temora discaudata (14.6\%), Pseudodiaptomus serricudatus (9.5\%), Undinula vulgaris (6.3\%) and Centropages orisinii (6.3\%) dominated in the samples. Cosmocalanus darwini, C. caroli, Lucicutia flavicornis, Euterpina acutifrons were found exclusively during premonsoon, whereas Subeucalanus mucronatus and Euchaeta longicornis were present only during postmonsoon (Table 3). No spatial differences in the distribution of calanoid copepods were observed. Cyclopoid copepods had representatives of three families, Corycaeidae, Oithonidae and Oncaedae. The species Oithona similis (9.4\%), Corycaeus agilis (8.1\%), Corycaeus vitreus (4.3\%) and Farranula gracilis (3.5\%) formed the major contributors to the total copepod density in premonsoon. Harpacticoid copepods had the representatives from three families, Euterpinidae, Ectinosomatidae and Miracidae and the species Euterpina acutifrons $(7.2 \%)$ was most abundant in premonsoon. The Shannon-Weiner diversity index $\left(\mathrm{H}^{\prime}\right)$ was higher in premonsoon (4.55), while species richness (d) (6.69) and evenness (0.88) was high during monsoon (Figure 4). Species diversity and richness showed the lowest value during postmonsoon.

\section{Discussion}

This study provides a comprehensive understanding on the mesozooplankton distribution and community composition, in relation to various hydrographic parameters in Kavaratti atoll in which limited information is available. The water temperature, salinity and $\mathrm{pH}$ in the atoll were higher throughout the study period. The same was reported by Goswami (1973) and the values (temperature, 29.7 to $31.9^{\circ} \mathrm{C}$; salinity, 34.15 to $35.64 \mathrm{psu} ; \mathrm{pH}, 7.9$ to 8.3 ) were comparable with the present study. Occurrence of high values of all these parameters could be attributed to shallow depth of the atoll. Further, Qasim and Sankaranarayanan (1970) proposed that heavy surf breaking across the reef creates a unidirectional flow of seawater towards the entrance of the lagoon, which may also contribute to high salinity. The change in salinity, particularly during south west monsoon season (June to September) could be attributed to the fresh water influx due to precipitation. Higher $\mathrm{pH}$ observed during the study period would help in the precipitation of calcium carbonate that facilitates the coral development (Clansen and Roth, 1975). Prevalence of saturated condition of dissolved oxygen value irrespective of the stations and seasons could be due to the active photosynthesis by seaweeds as well as sea grasses (Robin et. al. 2012).

The concentration of nutrients in the present study indicates oligotrophic nature of the water. Incidence of comparatively high values of nitrate, nitrite and phosphate, particularly in the coral area during monsoon season might be due to the discharge of the domestic sewage and leaching from the coir spinning industries located along the coast. The prevalence of low nutrient concentrations in other seasons could be due to their increased utilization by macrophytes, and low retention by the sandy substratum (Neudecker et. al. 1987). This agrees with the earlier works in the same area (Robin et.al. 2012). Concentration of silicate did not show marked variation as there was no fresh water influx from the river. A comparatively low value of ammonia in the study area is probably due to its increased uptake by the phytoplankton community which is preferred over nitrate in certain environmental conditions (Wafar et. al.1985).

Zooplankton density in Kavaratti atoll ranged from 145 to 1475 ind./m3, which is higher than that of Suresh et. al. (1997), who reported zooplankton density ranging from 122 to $722 \mathrm{ind} / \mathrm{m}^{3}$ in day time samples. Madhupratap et. al. (1977) reported that compared to Agatti and Suhelipar lagoon in Lakshadweep, zooplankton density was lower in Kavaratti as former lagoons were larger and deeper with higher carrying capacity. 
Seasonality in mesozooplankton abundance may be associated with variation in physico chemical parameters. The results agree with the findings of Chicharo and Chicharo (2000) who proposed that structure and distribution of zooplanktonic communities in lagoons is influenced by the various physico chemical parameters like temperature, salinity, $\mathrm{pH}$, nutrients, dissolved oxygen, biological (chl-a) and topographical parameters. Therefore, highest mesozooplankton density and biomass in postmonsoon could be related to the high values of salinity, $\mathrm{pH}$ and dissolved oxygen and the lowest abundance during monsoon corresponds to comparatively low values of these parameters. In addition, Nasser et. al. (1988) suggested that rainfall adversely affects the mesozooplankton abundance due to factors such as low light intensity, high current velocity and high turbidity (Nassser et. al. 1988; Goswami, 1973). Lack of significant correlation between zooplankton density and chlorophyll a concentration may be due to the dependence on other alternative food sources such as detritus or organisms of the microbial pathway when phytoplankton is quantitatively or qualitatively inadequate (Gaudy et. al.1995). Sale et. al. (1976) reported that substratum plays a crucial role in regulating zooplankton density. So, highest abundance of mesozooplankton in coral area and near boat channel was probably due to the lack of shelter as both stations are located in a sandy area (Goswami, 1973). On the contrary, abundance of mesozooplankton inside the lagoon could be due to grass foliage, which provides more shelter.

Despite moderately high density during premonsoon season, the lower biomass in coral area and near boat channel was due to the dominance of small sized cyclopoid copepods. On the other hand, high biomass inside the lagoon in the same season was attributed to the dominance of fish larvae. A total of 14 mesozooplankton taxa were observed in the present study. The number of the taxa was similar to that of Rosamma (2001), but reported a sharp decline from 1982, when about 23 zooplankton taxa were recorded. Copepods dominated in all stations and seasons as in most tropical and subtropical waters (Cornils et. al. 2010). The results also agree with other findings in Kavaratti atoll (Nasser et. al. 1998; Madhupratap et. al. 1991). On the contrary, Madhupratap et. al. (1977) observed domination of molluscan larvae in the zooplankton, while Suresh et.al. (1997) reported the dominance of fish eggs and larvae in day time samples from Kavaratti. Dominance of cyclopoid copepods during premonsoon may be due to the change in food availability by change of phytoplankton composition from microphytoplankters to pico, and nanoflagellates which is proposed as an important factor for the increase in the abundance of small species as they are unable to feed diatoms (Doi et. al. 2008).

In Kavaratti atoll 30 calanoid, 10 cyclopoids and 5 harpacticoids were recorded. The total number of species reported in the present study was comparatively higher than other reports from the same area (Madhupratap et.al. 1977; 1991; Jean et. al. 2010; Robin et. al. 2012). Among the calanoids, the families Candacidae, Calanidae, Pontellidae, Temoridae, Psuedodiaptomidae, Centropagidae and Oithonidae were dominated. Goswami and Usha (1990) reported the same families in addition to Paracalanidae, Acartidae, Euchaetidae, Scolecithridae, and Pseudocalanidae also displayed higher abundance. Generally, among copepods the genera Candacia, Calanopia, Temora and Oithona were dominated during the study period. In contrast, Madhupratap et. al. (1977) reported that the genera, Paracalanus and Acrocalanus contributed greatly to the calanoid copepod composition, while Goswami et. al. (1973) reported the dominance of harpacticoid copepod species inside the lagoon. Many species that were reported to be abundant in previous studies were not found to be occurring in the present study (Madhupratap et. al. 1977; 1991; Jean et. al. 2010; Robin et. al. 2012). This may be due to the difference in sampling intensity of the present study compared to the previous works, which were mostly focused on diel variation in zooplankton distribution. Among the 30 identified calanoid species, 20 species have already been reported from the Kavaratti atoll (Madhupratap et. al. 1977; 1991; Jean et. al. 2010, Robin et. al.2012). Mesopelagic as well as benthopelagic species occurred rarely in the samples that substantiate to the fact that depth of the water body plays an important role in zooplankton community composition (Schmitt, 2007). The species reported from the present study, Euchaeta marina, Euchaeta longicornis, Cosmocalanus darwini, Subeucalanus mucronatus, Subeucalanus subcrassus, Temora discaudata, Centropages furcatus,Candacia bradyi, Candacia catula, Candacia simplex Acartia negligens and Acartia amboinensis, were restricted to Indian and pacific oceans (Madhuprathap and Haridas, 1986). Though the species like Cosmocalanus caroli, Bestiolina similis, Calocalanus plumulosus, Euchaeta longicornis, Lucicutia flavicornis, Pseudodiaptomus serricaudatus, Candacia simplex, Temora tarbinata, Acartia centrura and Acartia amboinensis have already been reported from Indian ocean, they were first time reports to the Kavaratti lagoon.

\section{Conclusion}

The present study attempted to provide a baseline data on mesozooplankton community composition based on seasonal sampling. It is evident that mesozooplankton community in the study area was more susceptible to variation on temporal scale rather than spatial scale according to the variation in abiotic parameters therefore can be used as potential indicators of water quality. 


\section{Acknowledgements}

Authors are thankful Department of Biotechnology, Government of India for the financial support and to the Head of the Department of Marine Biology, Microbiology and Biochemistry, School of Marine science, Cochin University of Science and Technology for providing necessary facilities to carry out the work. The help rendered by Department of Science and Technology, Union Territory of Lakshadweep in giving research permission and other logistic support are specially remembered.

\section{Reference}

[1]. Chiba, S., Tadokoro, K., Sugisaki, H. Saino,T. Effects of Decadal Climate Change on Zooplankton Over The Last 50 Years In The Western North Pacific. Global Change Biology 12, 2006, 907-920.

[2]. Kusum, K.K., Vineetha, G., Raveendran, T.V., Nair, V.R., Muraleedharan, K.R., Achuthankutty, C.T. \& Joseph T , Chaetognath community and their responses to varying environmental factors in the northern Indian ocean. Journal of Plankton Research 36(4), 2014, 1146- 1152 .

[3]. Madhupratap, M., Achuthankutty, C.T. \& Sreekumaran Nair, S. R., Zooplankton of the Lagoons of The Laccadives: diel patterns and emergence. Journal of Plankton Research. 13, 1991, 947-958.

[4]. Cornils, A., Schnack-Schiel, S.B., Hagen, W., Dowidar, M., Stambler, N., Plahn, O., Richter, C., Spatial and temporal distribution of mesozooplankton in the Gulf of Aqaba and The Northern Red Sea in February/March 1999. Journal of Plankton Research. 27 (6), 2005, 505-518.

[5]. Bakus, G.J. Coral Reef Ecosystems (Oxford \& IBH Publishing Co. Pvt. Ltd. New Delhi, 1993).

[6]. Qasim, S.Z. \& Sankaranarayanan, V.N.,Production of Particulate Organic Matters By The Reef on Kavaratti Atoll (Lacadive). Limnology and Oceanography. 15, 1970, 574-578.

[7]. Qasim, S.Z., Bhattathiri, P.M.A. \& Reddy, C.V.G.,Primary Production of an Atoll in the Laccadive. Internationale Revue Der Gesamten Hydrobiologie Und Hydrographie 57, 1972, 207-225.

[8]. Tranter, D.J. And George, J., Zooplankton abundance at Kavaratti and Kalpeni atolls in the Laccadives. Proceedings of the first International Symposium on Corals and coral reefs, 12-16 January 1969; India: Marine Biological Association Of India. 1972, 239256.

[9]. Goswami, S.C., Observations on some planktonic groups of Kavaratti atoll (Laccadives). Proceedings of The National Academy of Sciences, India Section B: Biological Sciences 39b, 1973, 676-686.

[10]. Goswami, S.C., Diel variation of zooplankton at Kavaratti atoll (Lakshadweep). Indian Journal of Marine Sciences 8, 1979, 247251.

[11]. Madhupratap, M., Wafar, M.V.M., Haridas, P., Narayanan, B., Gopala Menon, P. And Sivadas, P., Comparative studies on the abundance of zooplankton in the surrounding Sea and lagoons in the Lakshadweep. Indian Journal of Marine Science. 6, 1977, 138141.

[12]. Strickland, J.D.H., Parsons, T.R., A Practical Handbook of Seawater Analysis. (Fisheries Research Board Of Canada, 1972).

[13]. APHA., Standard Methods for The Examination of Water And Waste Water. (21 $1^{\text {st }}$ edition, Washington DC, 2005).

[14]. Grasshoff, K., Ehrhardt, M. \& Kremling, K.,Methods of Sea water Analysis. (3rd Ed. Verlag Chemie, Weinheim, Germany, 1999).

[15]. Harris, R., Wiebe, P., Lenz, J., Skjoldal, H. \& Huntley, M., ICES Zooplankton Methodology Manual. (Academic Press Inc., United States,2000).

[16]. Goswami, S.C., Zooplankton Methodology , Collection \& Identification - A Field Manual. (National Institute Of Oceanography, India,2004).

[17]. Johnson, W.S. \& ALLEN, D.M., Zooplankton of the Atlantic and Gulf Coasts - A Guide To Their Identification And Ecology. (Johns Hopkins University Press, Baltimore, Maryland, 2005).

[18]. Tait, R.V. Elements of Marine Ecology. (Third Edition, Butterworths London Des Especes Novuvelles. Bulletin De l'Institut Océanographique De Monaco, 1981).

[19]. Omori, M. And Ikeda, T., Methods in Marine Zooplankton Ecology, (A Wiley Interscience Publication, John Wiley And Sons. United States, 1984).

[20]. Todd, C.D., Laverack, M.S., Coastal Marine Zooplankton: A Practical Manual for Students. (Cambridge University Press, 1991).

[21]. Mori, T., The Pelagic Copepoda From The Neighbouring Waters Of Japan. (The Soyo Company Inc, Japan, 1964).

[22]. Sewell, R.B. And Seymour, the Free-Swimming Planktonic Copepoda. Systematic Account. Scientific Reports of The John Murray Expedition 8 (1), 1947, 1-303.

[23]. Sewell, R.B.S., The Free Swimming Planktonic Copepod. Geographical Distribution. Scientific Reports of the John Murray Expedition 8, 1948, 317-592.

[24]. Kasturirengn, L.R., A Key Identification of the More Common Planktonic Copepods of Indian Waters. (CSIR Publications, New Delhi, 1963).

[25]. Wellershaus, S., On the Taxonomy of Planktonic Copepoda in the Cochin Backwater (A South Indian Estuary). Veröffentlichungen Des Instituts Für Meeresforschung In Bremerhaven 11, 1969, 245-285.

[26]. Bradford, J.M. And Jillett, J.B., The Marine Fauna of New Zealand: Pelagic Calanoid Copepods: Family Aetideidae. Memoirs. N Z Oceanographic Institute 86, 1980, 1-102.

[27]. Bradford, J.M., Grieve, The Marine Fauna of New Zealand: Pelagic Calanoid Copepoda, Megacalaniidae, Calanidae, Paracalanidae, Mecynoceridae, Eucalanidae, Spinocalanidae, Clausocalanidae. (New Zealand Oceanographic Institute Memoir. NIWA, Wellington, 1994).

[28]. Conway, V.P., Rowena, G.W., Joanna, H.D.C., Christopher, P.G. And David, B., Guide To the coastal and surface zooplankton of the South - Western Indian Ocean. (Marine Biological Association of The United Kingdom, Occasional Publication No. 15, 2003).

[29]. Clarke, K.R. And Gorley, R.N., PRIMER V 6: User Manual/Tutorial, PRIMER-E. (Plymouth- Marine Laboratory. Plymouth, UK.192, 2006).

[30]. Clansen, C.D. And Roth, A.A., Effect of temperature and Temperature adaptation on calcification rate in the Her-matypic coral Pocillopora damicornis. Marine Biology 33, 1975, 93-100.

[31]. Robin, R.S., Pradipta, R., Vishnuvardhan, K., Nagarjuna, A., Nallathambi, T., Rajani, K.M. And Balasubramanian, T., Planktonic communities and trophic interactions in the Kavaratti waters, Lakshadweep archipelago, India. International Journal of Ecosystem 2 (2), 2012, 5-18.

[32]. Neudecker, S., Environmental effects of power plants on CoralrReefs and ways to minimize them. In: Human Impacts on Coral Reefs: Facts and Recommendations. Antenne Museum EPHE, French Polynesia, 1987, 103-118. 
[33]. Wafar, M.V.M., Wafar, S., Devassy, V.P., Nitrogenous nutrients and primary production in a tropical Ocean environment. Bulletin of Marine Science 38, 1985, 273-284.

[34]. Suresh, V.R. And Mathew K.J., Zooplankton ecology in Kavaratti atoll, Lakshadweep, India. Indian Journal of Fisheries. 44(3), 1997, 271-277.

[35]. Chicaro, L.M.Z. And Chicaro, M.A., Short-term fluctuations in bivalve larvae compared with some environmental factors in a coastal lagoon (South Portugal). Scientia Marina 64, 2000, 413-420.

[36]. Nasser, A.K.V., Siraimeetan, P. And Aboobaker, P.M., Zooplankton abundance and distribution at Minicoy lagoon, Lakshadweep. Indian Journal of Marine Science. 27, 1998, 346-350.

[37]. Gaudy, R., Verriopoulos, G. And Cervetto, G., Space and time distribution of zooplankton in A Mediterranean Lagoon (Etang De Berre). Hydrobiologia, 300-301, 1995, 219-236.

[38]. Sale, P.F., Mcwilliam, P.C. And Anderson, D.R., Composition of the-reef zooplankton at Heron reef, Great Barrier Reef. Marine Biology 34, 1976, 59-66.

[39]. Rosamma, S., Biodiversity and density of zooplankton on the decline in Kavaratti atoll (Lakshadweep, Arabian Sea) A multidecadal Study. Proceedings of Workshop on Scientific Database of Lakshadweep Islands: 6-7 December 1995: Kochi, India. Geological Survey Of India, Special Publication No. 56, 2001, 133-138.

[40]. Cornils, A., Schulz, J., Schmitt, P., Lanuru, M., Richter, C. And Sigrid, B.S., Mesozooplankton distribution in the Spermonde archipelago (Indonesia, Sulawesi) With Special Reference To The Calanoida (Copepoda). Deep Sea Research Part II, 2010, 20762088.

[41]. Doi, H., Chang, K.H. And Obayashi, Y., Attached microalgae contribute to planktonic food webs in bays with fish and pearl farms. Marine Ecology Progress Series 353, 2008, 107-13.

[42]. Jean Jose, J., Udayakumar, P., Ajimon, V.J., Shibu, R., Narendrababu, R. And Baiju, R. S., Hierarchical analysis of zooplankton assemblages over semidiel pattern in the lagoon of Kavaratti atoll, Lakshadweep archipelago, India. Current Research Journal Of Biological Sciences 2(4), 2010, 294-298.

[43]. Goswami, S.C. And Usha, G., Diel variation in zooplankton in Minicoy lagoon and Kavaratti atoll (Lakshadweep Islands). Indian Journal Of Marine Sciences .19, 1990, 120-124.

[44]. Schmitt, P., Environmental influence on the distribution and community structure of mesozooplankton in the Spermonde Archipelago, Indonesia. University Of Bremen, Germany, 2007.

[45]. Madhupratap, M. And Haridas, P., Epipelagic calanoid copepods of the Northern Indian Ocean. Oceanologica Acta 9, 1986, 105117 . 